\title{
Suspected Vibration Magnitude on the Body of Chain Saw Users among National Forest Workers in Kyusyu, from 1956 to 1984
}

\author{
TADAYOSHI SAKURAI \\ Department of Environmental Medicine, Kurume University School of Medicine, \\ Kvrume, 830 Japan
}

Received for publication June 30, 1989

\begin{abstract}
Summary: Chain saws were first used in Kyusyu in 1956 for cutting down trees and sawing timber in the national forests. In 1961, some workers complained of symptoms due to the vibrations, but countermeasures were not taken untill later. The working system and payment system in those times were different from the systems, today. The magnitudes of the chain saw vibrations were very large and the chain saws were operated for many hours, each day. Workers with VWF (vibration induced white finger) had to continue to operate the chain saws without restriction. Vibration disease is related primarily to the vibration of the tools, but also to the transmission of the vibration to the workers. From the official data on chain saws used in national forests, vibration transmission to the body was determined for workers from 1956 to 1984 by comparing the vibration magnitude on the body during work with modern chain saws and during vibration loading tests with an electrodynamic shaker in the laboratory. The vibrations transmitted to the body in some rule in the observation. If the working posture of chain saw operator was the same as today, the vibration transmission was determined from the tool vibration, tool weight, joint fixation and orientation of the hands and the hands and the arms to the handle (joint elasticity). Older chain saws had 20 to 30 times larger vibration magnitudes than modern chain saws, and were also 2 to 3 times heavier. The vibrations transmitted to the foreheads of earlier workers were approximately the same magnitude as the vibrations at the back of the hands of present workers. Also the daily and annual hours of chain saw use were very long, and there were not sufficient measures to protect from the cold. The vibration in the former days led to more symptoms and lesions than in present times.
\end{abstract}

Key words: vibration transmission - vibration exposure - chain saw-extent of lesion - mass - elasticity (joint fixation)

\section{Introduction}

In 1956 chain saws were introduced for cutting down trees and for sawing timber into pieces in the Kyusyu national forest (labour agreements collections). At first, one chain saw was used by two men in rotation, but after 1960 it was operated by one man. There was no la- bour agreement concerning working time and working hours, and payment was based on daily piecework. The year after the introduction of the one-man saws, some workers complained of Raynaud's phenomenon during the Winter. But nothing was done about it untill 1970. The 8 hour workday was introduced even in 1969. The magnitude and dose of vibra- 
tion exposure was very different from present exposures, the clinical features of those disturbances were probably also different. This report compares the vibration magnitudes in the body and the vibration transmission by calculating it from previous data of chain saw vibrations and from data obtained by observing the vibrations in the body during chain saw work.

Disturbances due to vibration are influenced by the magnitude of the vibration transmitted from the tool and the total hours of exposure, The extent of the lesions is determined by the degree of vibration transmission and the absorption by the tissues. In Japan there are some official reports concerning the magnitudes of vibrations from chain saw handles after 1960 (Yamawaki, 1980; Sasaki, 1985), but the reports concerning vibration transmission were not available untill 1978.

By measuring vibration magnitudes on various parts of body during the operation of chain saws and by an experimental loading of sine curve vibrations to the hand-arm system, vibration transmission was observed to vary with mass, joint fixation, frequency of vibration, and the magnitude of the source vibration. Then the vibration transmission to the bodies of the users in previous years was calculated.

\section{Methods}

Measurement of vibration magnitudes and noise of some tools

The vibration and noise of the tools were measured according to IS 5349, JIS C1511, JIS Z8735 and JIS Z8731. Vibration was measured in three axes, $X$ (vertical), $Y$ (sideway) and $Z$ (fro and aft) in the 3rd metacalpal bone, while operating the chain saws.

For measuring vibration, an accelero- meter (RION, PV-93) with 3 pickups was tightly fixed to the handle of the tools with a hose band. The signals from the accelerometer were amplified with RION VM-17s and were recorded on a datarecorder (TEAC, R-71). Noise was recorded concurrently with vibration, which was measured at the side of the user's ear with a microphone (RION, UC-26) attached to the operator's helmet. All signals were analyzed for frequency components into $1 / 3$ octave bands by signal analyzers (RION SA-33D, RION SA-12) and were drawn on a levelrecorder (RION, LR-04). The toal capability of the measuring and analyzing system was $\pm 1 \mathrm{~dB}$ between 5 and $1250 \mathrm{~Hz}$. Moreover vibration acceleration level was expressed as $20 \log _{10}$ A/Aref and $10^{-5} \mathrm{~m} / \mathrm{s}^{2}$ was taken as Aref.

Measurement of vibration magnitudes at different points on the body

Vibrations on the back of the hand, the forearm and the forehead were measured from the surface of the skin by small light pickups weighting 1.4 grams (BBN, F501) that were attached with adhesive tape. Signals were amplified with a TEAC SA-16, recorded on a datarecorder and analyzed with a signal analyzer.

An experimental room vibration loading tests using an electrodynamic shaker was

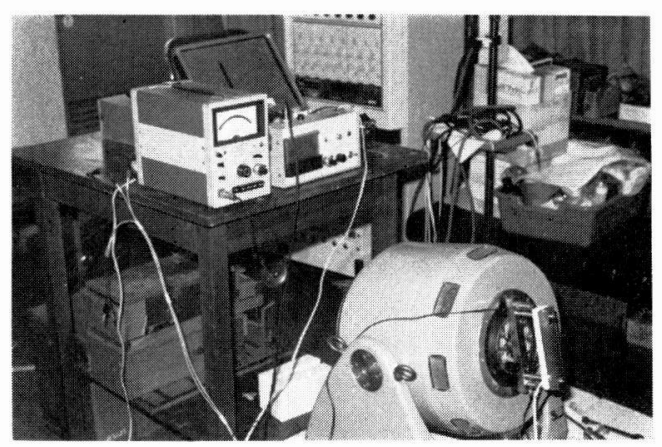

Fig. 1. The vibration loading system using an electrodynamic shaker which keeps the vibration and grip force constant. 
performed to observe the vibration transmission and factors which influence it (AKASHI, ASE-12 and ASE-600). Sine curve vibrations of $25,31.5,40,50,63$, $80,100,125,160,200,250$ and $315 \mathrm{~Hz}$ were used for the loading tests. The shaker was set to transmit a vibration horizontally to the subject's hand through the handle, as illustrated in Fig. 1.

The subject gripped the handle of the shaker and maintained a constant grip force which was displayed on an indicator (TOYODA, LOAD METER) that measured the output from a loadmeter mounted on the handle of shaker. The vibration was transmitted to the subject's hand in the direction of the longitudinal axis of his forearm and was monitored on the handle of shaker, the back of hand, the forearm and the forehead.

\section{Results and Discussion}

The analysis of the vibration and noise of the tools are shown in Table 1 and Fig. 2. These were the largest values for the three axes. The vibration spectra of these tools are different depending on the

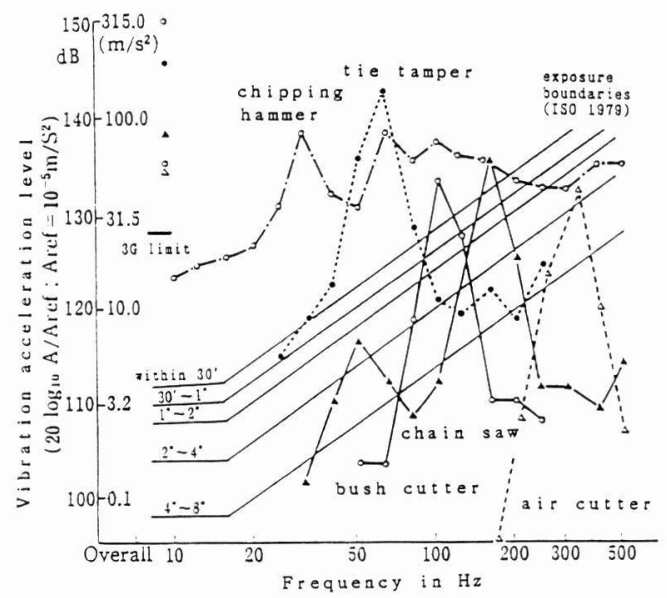

Fig. 2. The vibration spectra of different vibrating tools.

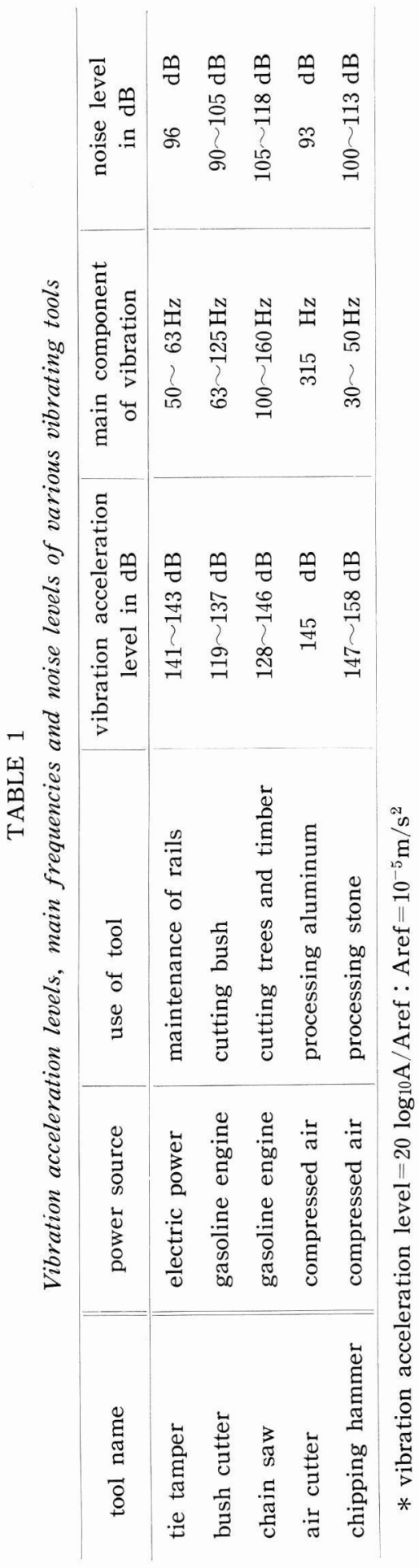




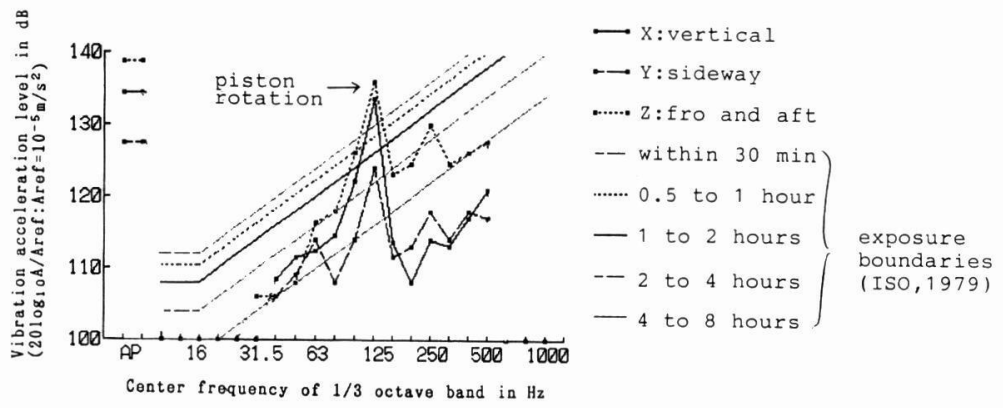

Fig. 3. The vibration spectra of chain saw while being used to cut timber into pieces (piston rotation is approximately $7000 \mathrm{rpm}$ ).

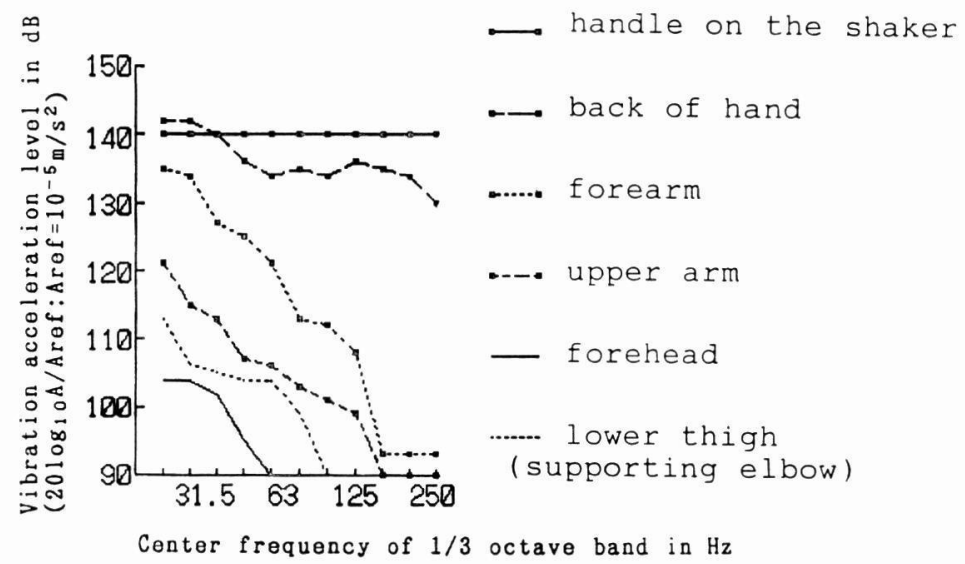

Fig. 4. The inforced vibration to the hand from the electrodynamic shaker and the transmitted vibration to other parts of the body (measurement direction is fro and aft).

power source, the use, the materials etc. The tie tamper has sharp main components at 50 to $60 \mathrm{~Hz}$. It is used for the maintenance of rail tracks to tie the pebblestones under the rails by vibration and weight. The main components from the bush cutter occur at $100 \mathrm{~Hz}$, for the chain saw at $160 \mathrm{~Hz}$ and for the aircutter at 315 $\mathrm{Hz}$. The main components from each tool had very sharp peaks. The chipping hammer had main components at 30 to $40 \mathrm{~Hz}$ and had other harmonic peaks around the main peak, because the chisel of the chipping hammer scraps rocks by impacts at approximately $2000 \mathrm{rpm}$. These features of the tools influenced the vibration transmission to the body.

Figure 3 shows a vibration spectra of a chain saw being used to cut timber. Vibrations in the $\mathrm{X}$ and $\mathrm{Z}$ directions were larger than those in the $\mathrm{Y}$ direction. The main component of the chain saw vibration was due to the piston rotation $(7000$ $\mathrm{rpm}$ ) and was $125 \mathrm{~Hz}$. Other factors such as chain movement and cutting action were less intense than the piston rotation. The vibration in the $Z$ direction showed the largest value in the handle, and it 
has a similar longitudinal axis as the forearm and thus transmitted more vibration to the body than the other components.

Figure 4 shows the vibration transmission to the body from the handle of a shaker with fro and aft movements at frequencies of 25 to $315 \mathrm{~Hz}$. Five attenuation curves were obtained. The back of the hand vibrated larger than the source vibration between 25 and $40 \mathrm{~Hz}$, but the vibration was attenuated by $5 \mathrm{~dB}$ between 60 and $200 \mathrm{~Hz}$. The forearm vibration was $5 \mathrm{~dB}$ smaller than the source vibration at $25 \mathrm{~Hz}$ and was attenuated 10 to $12 \mathrm{~dB} / \mathrm{oc}$ tave above $25 \mathrm{~Hz}$. The upper arm and forehead vibrations were small, but the attenuation curves were very similar to those for the forearm. When the subject rested his elbow on his thigh during the loading test, the vibration was also transmitted to his thigh.

The elastic modulus between the bones, and between the handle and hands influenced the vibration transmission. Figure 5 shows that all components of the vibration were transmitted from the handle to another mass without attenuation, if there was no elastic body between them; but it was amplified at low frequencies and attenuated at high frequencies, if there was an elastic body between them. That attenuation changed with the elastic modulus of the soft tissues. The peak frequency was considered to be the reso- nance, because of the physical mass and elasticity. With the equation, $\mathrm{F}=\mathrm{K} \times \mathrm{X}=$ $\mathrm{M} \times \mathrm{A}$ ( $\mathrm{F}$ : force, $\mathrm{K}$ : elastic modulus, $\mathrm{X}$ : displacement, $\mathrm{M}$ : mass, $\mathrm{A}$ : acceleration), the frequency of the resonance could be obtained by the next formula.

$\mathrm{f}=\frac{1}{2} \cdot \sqrt{\mathrm{K} / \mathrm{M}}$ ( $\mathrm{f}$ : frequency of resonance)

Therefore the resonance moves to higher frequencies with an increasing elastic modulus, which means that the tighter the fixation becomes, the better the vibration is transmitted at high frequencies. By the above formula, as the fixation of fhe joint becomes 2 or 3 times larger, the resonance moves $\sqrt{2}$ or $\sqrt{3}$ times higher in frequency. It is also influenced by transmission of high frequency vibrations above the resonance. Vibrations of the forearm and forehead were recorded while cutting timber with a chain saw (Fig. 6). The lower frequency vibrations were transmitted with less attenuation, and the higher frequency vibrations were transmitted with more attenuation. When compared to Fig. 4, the attenuation of high frequency vibrations was smaller during work than during the experimental loading test.

Figure 7 shows the vibration accelerations from chain saw handles manufactured each year, from a report in which vibrations of chain saws produced after 1965 were measured (Yamawaki, 1980;

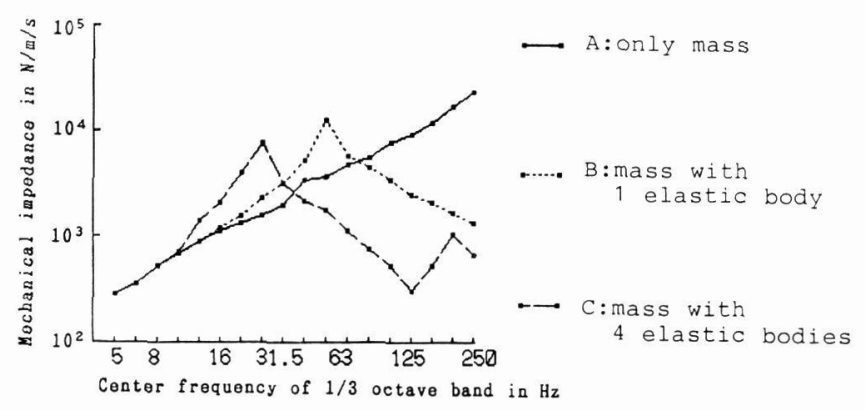

Fig. 5. Mechanical impedance, inforced vibration and elastic modulus between the handle and the mass. 


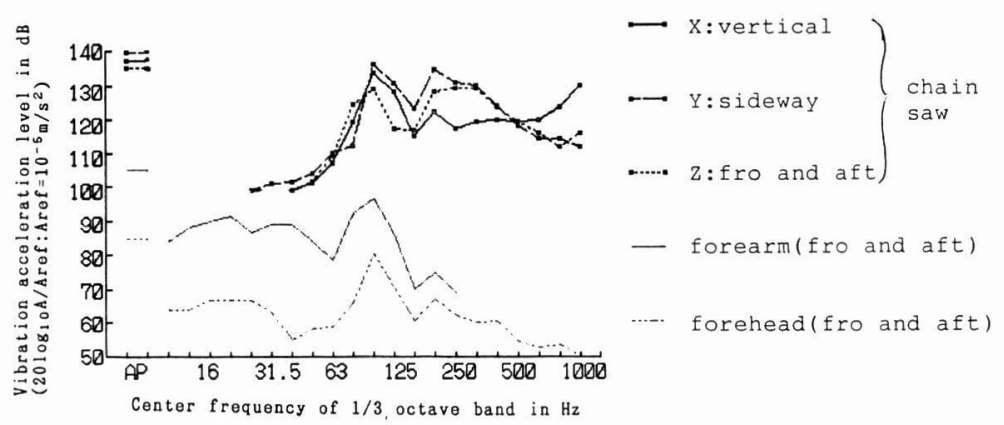

Fig. 6. The spectra of the chain saw vibration in the handle and the transmitted vibration in a forearm and a forehead of a user.

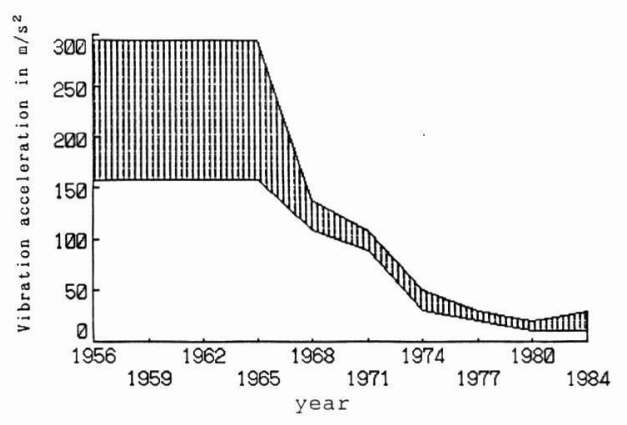

Fig. 7. The vibration acceleration in the handles of chain saws in the national forests from 1956 to 1984 .

Sasaki, 1985). Before 1965 the chain saws were used without restrictions, thus the levels of chain saw vibrations in 1965 were extended to 1956 in the figure. The report indicates that the vibration magnitudes were 20 to 30 times larger at the handles of the old chain saws than at the handles of modern chain saws. After steps to introduce antivibration devices the vibration acceleration was reduced to less than $29.4 \mathrm{~m} / \mathrm{s}^{2}(3 \mathrm{G})$. The weights of the old chain saws wers 2 to 3 times heavier than the modern chain saws.

The vibration transmission was dependent on the magnitude and the main components of the tool vibrations, and the elasticity or fixation, between the handle and the hand, and between the joints.
The vibration transmission in earlier days could be estimated from the data of vibration magnitudes of the chain saws in those days and vibration transmission tests during work and experimental design tests. The shapes of vibration attenuation curves varied according to the frequency and components of the tools, but not with the magnitudes of the vibrations (Pyykkö, et al. 1976; Sakurai, 1984). The magnitudes of the tool vibrations were related to the vibration magnitudes at different parts of the body. Fixation of joints influenced the resonance, and weight of the tool and grip power were related to the fixation of joints, namely the elasticity between the handle and the hand, and between the bones. The tool weight influenced the vibration transmission by changing the resonance. By measuring the vibration transmission during chain saw work, it could be concluded that resonance exists at $\sqrt{2}$ to $\sqrt{3}$ times higher frequencies in the older chain saws than in modern chain saws because of the tool weight. Vibration attenuation curves move a half octave higher with each doubling of weight and 0.8 octave higher with each tripling of weight. With the hand-arm system, vibration transmission was attenuated in amplitude by 10 to $12 \mathrm{~dB} / \mathrm{oc}$ tave and then the vibration transmission during chain saw work increased by 5 to $6 \mathrm{~dB}$ from a calculation of 10 to $12 \mathrm{~dB} / \mathrm{oc}$ - 


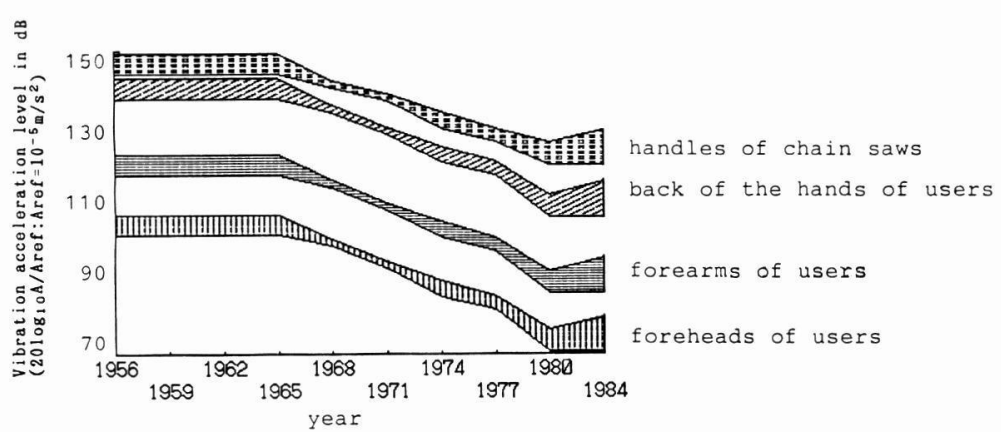

Fig. 8. The suspected vibration acceleration levels at the back of the hand, the forearm and the forehead from 1956 to 1984 .

tave multiplied by 0.5 octave, or 8 to $10 \mathrm{~dB}$ by 10 to $12 \mathrm{~dB} /$ octave by 0.8 octave. The vibration magnitudes of older chain saws were 20 as to 30 times greater than modern chain saws, thus this becomes 26 to $30 \mathrm{~dB}$. Finally vibration transmission by older chain saws was $31 \mathrm{~dB}$ to $40 \mathrm{~dB}$ greater than by modern chain saws.

Figure 8 shows the suspected vibration magnitude at some parts of the body as determined by the above formula. The vibration magnitudes at the foreheads of early chain saw users were the same as the vibration magnitudes at the backs of the hands of present chain saw users. Taylor stated that 8 to 15 of 1000 workers had to change their jobs, even after the introduction of AV-saws (anti-vibration chain saws) (Taylor, W. in Statement, 1981). The vibration levels at the foreheads of earlier workers cannot be ignored, considering that vibration syndrome occured in those days. The next important factor to consider is how long they used the chain saws, each day, and how long those working conditions continued. Some differences were observed in the history of the occurrence of vibration syndrome and countermeasures taken in Japan and in other countries which use a forestry land to produce timber.

Table 2 shows chronologically the working conditions, occurrence of vibration syndrome and care for patients after the introduction of the chain saw into the national forest in Kyusyu. Vibration syndrome broke out after the introduction of the one-man saw system in 1961, which prolonged the daily working hours with the chain saws. But no countermeasures were taken untill 9 years later. In 1970 workers with Raynaud's phenomenon were restricted in their use of chain saws and were given different jobs (labour agreements collections). In 1975 vibrations at the handles of the new chain saws, introduced in the national forests, were less than $3 \mathrm{G}$. In the same year the vibration magnitudes of chain saw handles were restricted to less than $3 \mathrm{G}$ by a notification. That notification was only applied to new chain saws.

In the USSR chain saws were introduced for cutting trees and sawing timber in the national forests in 1956, and the next year some workers complained of symptoms of vibration syndrome. The $\mathrm{AV}$-saw was produced immediately and in 1958 temporary hygienic regulations to prevent vibration syndrome were developed by keeping the use of chain saws below $40 \%$ of the daily working hours, by providing warming rooms at the work places, by providing warm clothes and by introducing a special health check system. In 1966 this temporary regulation became a 
TABLE 2

Chronological observations on the working conditions for chain saw operators in the national forests of Kyusyu

\begin{tabular}{|c|c|c|}
\hline year & Working conditions & Complaints and care \\
\hline 1956 & $\begin{array}{l}\text { Introduction of the chain saw } \\
\text { with a two-man sawing system and } \\
\text { piecework payment }\end{array}$ & \\
\hline 1962 & Change to a one-man sawing system & $\begin{array}{l}\text { Complaints of VWF among } \\
\text { users }\end{array}$ \\
\hline 1965 & $\begin{array}{l}\text { Education on setting a saw } \\
\text { Beginning of an } 8 \text { hour work day }\end{array}$ & Care of patients with VWF \\
\hline 1971 & $\begin{array}{l}\text { Restriction of use to less than } 2 \mathrm{~h} / \text { day } \\
\text { Workers no longer stayed at forest }\end{array}$ & $\begin{array}{l}\text { Patients with VWF could not } \\
\text { operate chain saws }\end{array}$ \\
\hline 1974 & $\begin{array}{l}\text { Transportation by a microbus } \\
\text { Introduction of the AV saw } \\
\text { Restriction of the tool handle } \\
\text { vibration to less than } 3 \mathrm{G} \\
\text { Working for a salary }\end{array}$ & Health checks for users \\
\hline 1980 & & \\
\hline
\end{tabular}

formal regulation to prevent the vibration syndrome (Sanitarnuie normui i pravila pri rabote s instrumentami, mechanizmami i oborudovaniem, sozdayushtchimi vibrastii, predavaemuie na ruki rabotayushtchich i po ogranitcheniyu obshtchei vibrastii rabotchich mest, 1966).

In England the chain saw was introduced into the national forests in 1961. The chain saws were used only for cutting down trees and the daily duration of use was about 1.5 to 2 hours. After 1967, the chain saws were also used for debranching, and the daily use increased to 4 to 5 hours (Taylor et al. 1971). The England Forestry Commission had considerd restricting the vibration magnitude of chain saws to less than $80 \mu \mathrm{m}$ in 1968 ; but patients with VWF (vibration induced white finger) were observed in the national forests in 1969, soon after the increased use of the chain saws (Taylor et al. 1971). A decision was made to restrict the chain saw vibrations to $32 \mathrm{~m} / \mathrm{s}^{2}$ and to shift to the production of $\mathrm{AV}$ saws. The chain saws were changed every year to keep the anti-vibration mechanism of the chain saw effective. A new chain saw with a warm handle was introduced in 1975 (Griffin, 1980).

In Finland there were some reports that chain saw use averaged 2.8 hours/day in 1961. The AV-saw was introduced in 1964. The daily working hours of chain 
saw operators increased to as much as 5.1 hours/day in 1967 and then vibration syndrome was frequently detected among chain saw workers (Turtiainen, 1974). In the 1970's warm clothing and warming rooms at work places, and chain saws with anti-vibration devices and with warm handles were introduced (Pyykkö, 1978).

Among forestry workers in every country vibration syndrome has become more common with increased hours of operating a chain saw. However there were differences from Japan, therefore the clinical features of Japanese patients were somewhat different from patients in other countries. Moreover the working environment in Japan was usually in the mountains, because almost all forests are in the mountains, and all the trees were cleared from an area, as shown in Fig. 9. The worker had to stay in a forest cottage during the work week.

Vibration syndrome is a disease caused by vibration. The vibration magnitude of the tools is very important. Vibration transmission influences the disturbances. The vibration magnitude at various parts of the body and the total exposure time are significant factors for inducing the

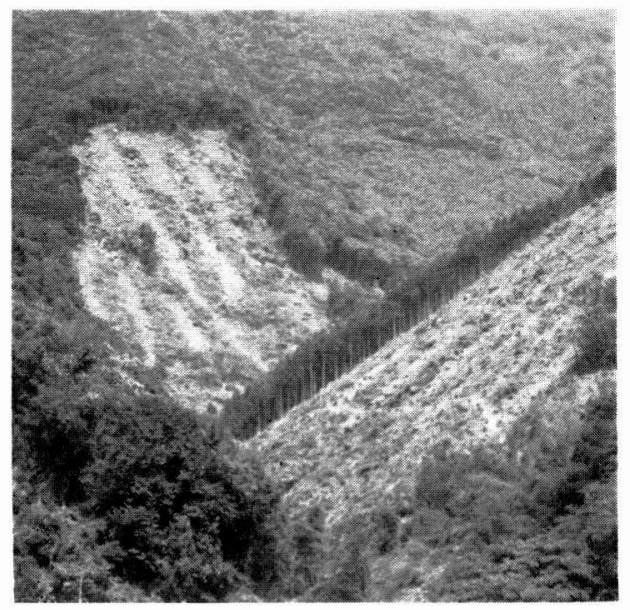

Fig. 9. The environment in the mountains after cutting down the trees. vicration syndrome. It is very difficult to discuss health hazards without comparing the history of the working conditions and the countermeasures taken. The occurrence of vibration syndrome increased in foreign countries as the daily use of chain saw increased, similar to Japan. But the steps to prevent the syndrome were taken sooner in other countries than in Japan. The lesions of vibration disease spread more widely throughout the body, as the time of exposure to large vibrations increased in Japan (Sakurai and Matoba, 1986).

\section{Conclusions}

The vibrations of tools differ depending on the power source, the use and the materials being processed. Eeach tool has distinctive components. A large sharp component in the chain saw spectra appears between 100 and $200 \mathrm{~Hz}$ when used to cut timber. This is caused by the piston rotation in the gasoline engine. The spectra of the transmitted vibration varies with the joint fixation, the magnitude and the spectra of the source vibration. Joint fixation is related to the elasticity between the handle and the hand, and the elas ticity between the bones, and it influences the resonance. Vibration attenuation curves in various parts of the body move from right to left with the resonance and move lower to upper with the magnitude of the vibration source. The vibration magnitudes at the foreheads of chain saw users before 1965 was similar to the magnitudes at the back of the hands of present chain saw users. Also, the vibrations in the forearms of early users is the same as the vibrations in the handles of modern chain saws. Such poor working conditions continued for at least 9 years in the Kyusyu forests. 


\section{References}

Griffin, M. J. (1980). Vibration injuries of the hand and arm: the occurrence and the evolution of standards and limits. Research $\mathrm{Pa}$ per 9, Health and Safety Executive, Her Majesty's Stationary Office, London.

PyykKö, I., Färkillä, M., Toivanen, J., Korhonen, O. and HyvÄrinEN, J. (1976). Transmisssion of vibration in the hand-arm-system with special reference to changes in compression force and acceleration. Scand. J. Work Environ. Health 2, 87-95.

Pyykkö, I., Sairanen, E., Korhonen, O., Färkkilä, M. and Hyvärinen, J. (1978). A decrease in the prevalence and severity of vibration-induced white fingers among lumberjacks in Finland. Scand. J. Work Environ Health 4, 246-254.

SAKURAI, T. (1984). Features of hand-arm vi- brations and health hazards due to tool vibrations in Japanese. J. Soc. Biomech. 8, 132-139.

Sakurai, T. and Matoba, T. (1986). Peripheral nerve responses to hand arm vibration. Scand. J. Work Environ Health. 12, 432-434.

SASAKI, N. (1985). Reduction of vibrations and noises of small tools on the hand in Japanese. J. Forestry Mechanization Society, 380, 58.

Taylor, W., Pearson, J., Kell, R. L. and Keighley, C.D. (1971). The vibration syndrome in forestry commission chain saw operators. Brit. J. Ind. Med. 28, 83-89.

Turtiainen, K. (1974). Chain saw vibration and vibration measurements. Work-Environ. Hlth. 11, 187-193.

YAMAWAKI, S. (1980). Report on observation of influences on users of anti-vibration chain saws in Japanese. 53-61. 